\title{
Phosphorylation of Mammalian Olfactory Cyclic Nucleotide-Gated Channels Increases Ligand Sensitivity
}

\author{
Frank Müller, Wolfgang Bönigk, Federico Sesti, and Stephan Frings \\ Forschungszentrum Jülich, Institut für Biologische Informationsverarbeitung, 52425 Jülich, Germany
}

In vertebrate olfactory sensory neurons, odorant receptors couple the sensory signal to the synthesis of the second messenger cAMP. Cyclic nucleotide-gated (CNG) channels are activated by binding of cAMP and conduct a depolarizing receptor current that leads to electrical excitation of the neuron. The sensitivity of olfactory CNG channels for cAMP can be significantly reduced by binding of calmodulin to a regulatory domain that resides within the $\mathrm{N}$-terminus of the $\alpha$-subunit of the channel. This regulatory domain also contains a consensus phosphorylation sequence for protein kinase $C$ (PKC). We have investigated the effect of channel phosphorylation by PKC and found that phosphorylation increases ligand sensitivity without counteracting modulation of the channel by calmodulin. We have identified the amino acid residue that is phosphorylated by PKC and have localized three isoforms of PKC in olfactory sensory cilia. The results of this study provide information about the control of ligand sensitivity in olfactory CNG channels by an intrinsic regulatory domain, representing both a calmodulinbinding site and a substrate for PKC.

Key words: cyclic nucleotide-gated channels; olfaction; sensory transduction; protein kinase C; protein phosphorylation; phorbol ester
Electrical excitation of olfactory sensory neurons (OSNs) in vertebrates is initiated by binding of odorants to receptor proteins in the plasma membrane of chemosensory cilia (Buck and Axel, 1991; Buck, 1992). The subsequent activation of adenylyl cyclase (Pace et al., 1985; Sklar et al., 1986; Lowe et al., 1989; Pfeuffer et al., 1989; Bakalyar and Reed, 1990; Boekhoff et al., 1990) causes an increase of the cAMP concentration within the ciliary lumen, and cyclic nucleotide-gated $(\mathrm{CNG})$ cation channels are activated by binding of cAMP (Nakamura and Gold, 1987; Kurahashi, 1989; Firestein et al., 1991; Frings et al., 1992; Lowe and Gold, 1993a; Zufall et al., 1994). CNG channels are expressed at high density in the ciliary membrane (Kurahashi and Kaneko, 1991) and conduct a receptor current that leads to depolarization and electrical excitation of the neuron.

Native CNG channels form hetero-oligomeric complexes (Chen et al., 1993; Bradley et al., 1994; Liman and Buck, 1994; Körschen et al., 1995; Liu et al., 1996). The best studied olfactory channel polypeptide is the $\alpha$-subunit, cloned from olfactory epithelia of various species (Dhallan et al., 1990; Ludwig et al., 1990; Goulding et al., 1992). Heterologously expressed $\alpha$-homomeric channels resemble native olfactory CNG channels in many respects (sensitivity to cGMP, lack of ligand-induced desensitization, cation permeability, blockage by divalent cations, and modulation by calmodulin); however, they clearly differ in some functional properties (sensitivity to cAMP and channel gating). A number of key characteristics of olfactory $\mathrm{CNG}$ channels have been elucidated through studies of heterologously expressed $\alpha$-subunits, and a particularly significant finding is that the ligand

Received Sept. 8, 1997; revised Oct. 20, 1997; accepted Oct. 23, 1997.

This work was supported by European Community Grant CHRX-CT94-0543 and Ministerium Für Wissenschaft und Forschung des Landes Nordrhein-Westfalen Grant IVA6-10201095. We gratefully acknowledge the assistance of Mechthilde Bruns, Helga Vent, and Helmut Erkens. We thank Drs. Benjamin Kaupp and Ingo Weyand for advice and discussions and Dr. Jonathan Bradley for roCNC DNA.

Correspondence should be addressed to Dr. Stephan Frings, Institut für Biologische Informationsverarbeitung, Forschungszentrum Jülich, 52425 Jülich, Germany.

Copyright (C) 1997 Society for Neuroscience $0270-6474 / 97 / 170164-10 \$ 05.00 / 0$ sensitivity is reduced by calmodulin (Chen and Yau, 1994; Liu et al., 1994) and, possibly, other $\mathrm{Ca}^{2+}$-binding proteins (Balasubramanian et al., 1996). The calmodulin-mediated modulation is expected to promote channel closure during adaptation when $\mathrm{Ca}^{2+}$ entry through $\mathrm{CNG}$ channels increases the ciliary $\mathrm{Ca}^{2+}$ concentration (Leinders-Zufall et al., 1997). Reduction of ligand sensitivity by binding of $\mathrm{Ca}^{2+} /$ calmodulin constitutes a negative feedback mechanism that terminates the receptor current (Kurahashi and Menini, 1997). Thus, regulation of ligand sensitivity is an important aspect for the role of CNG channels in olfactory signal transduction.

The activity of many ion channels is modulated through phosphorylation and dephosphorylation by a variety of protein kinases and phosphatases (for review, see Levitan, 1994). For CNG channels from rod photoreceptors, there is some evidence that phosphorylation modulates ligand sensitivity (Gordon et al., 1992). We investigated the expression pattern of protein kinase $C$ (PKC) isoforms in rat OSNs and measured the ligand sensitivity of heterologously expressed $\alpha$-homomeric olfactory CNG channels after stimulation of PKC. Here we show that the $\gamma, \delta$, and $\lambda$ isoforms of PKC are expressed in rat OSNs, and that activation of PKC leads to an increased ligand sensitivity of $\alpha$-homomeric channels. The effect of $\mathrm{PKC}$ is mediated by a serine residue located within a regulatory domain in the N-terminal region of the channel, which also harbors the binding site for calmodulin.

\section{MATERIALS AND METHODS}

Immunohistochemistry. Adult Wistar rats were anesthetized with fluothane and decapitated. The olfactory epithelium was excised and immersion-fixed in $0.1 \mathrm{M}$ phosphate buffer (PB), $\mathrm{pH} 7.4$, containing $4 \%$ paraformaldehyde, for $1 \mathrm{hr}$. After several rinses in PB, the tissue was cryoprotected in PB containing 30\% sucrose overnight, embedded in OCT compound (Miles, Elkhart, IN), and frozen at $-20^{\circ} \mathrm{C}$. Sixteenmicrometer-thick vertical sections (perpendicular to the mucosal surface) were cut on a cryostat and collected on gelatinized slides. Sections were air-dried, fixed in $4 \%$ paraformaldehyde for $5 \mathrm{~min}$, washed in $\mathrm{PB}$, and incubated in 10\% normal goat serum (NGS; Sigma, St. Louis, MO) and $0.5 \%$ Triton X-100 in PB for $1 \mathrm{hr}$. Anti-PKC antibodies (Transduction 
Laboratories, Lexington, KY) were diluted in $5 \%$ NGS, $0.5 \%$ Triton $\mathrm{X}-100$, and $0.05 \% \mathrm{NaN}_{3}$ in $\mathrm{PB}(\alpha, 1: 1000 ; \beta, 1: 2000 ; \gamma, 1: 4000 ; \delta, 1: 500$; $\epsilon, 1: 100 ; \lambda, 1: 250 ; \mu, 1: 500 ; \iota, 1: 100 ; \zeta, 1: 200)$. Sections were incubated overnight at room temperature with primary antibodies. After several rinses in $\mathrm{PB}$, sections were incubated in anti-mouse-biotin (Sigma, 1:80) diluted in 5\% NGS and $0.5 \%$ Triton X-100 for $1.5 \mathrm{hr}$, washed in PB, and subsequently incubated with ExtrAvidin-HRP (Sigma, 1:300) diluted in $\mathrm{PB}$ for $1.5 \mathrm{hr}$. After several rinses in $\mathrm{PB}$, antibodies were visualized using diaminobenzidine (DAB) as a chromogen $\left(0.05 \%\right.$ DAB and $0.01 \% \mathrm{H}_{2} \mathrm{O}_{2}$ in PB). Sections were covered with Mowiol (Hoechst Pharmaceuticals, Frankfurt, Germany) and photographed using Nomarski optics.

Electrophysiological measurements of ligand sensitivity. Human embryonic kidney (HEK) 293 cells were transfected with cDNA encoding the olfactory CNG channel $\alpha$-subunit of rat (Dhallan et al., 1990) or cattle (Ludwig et al., 1990) by calcium phosphate coprecipitation (Chen and Okayama, 1987) using the pcDNAI vector (Invitrogen, San Diego, CA) as described previously (Baumann et al., 1994). During phorbol ester treatment and patch-clamp experiments (Hamill et al., 1981), cells were held in a solution containing (in $\mathrm{mm}$ ): $120 \mathrm{NaCl}, 5 \mathrm{NaOH}, 3 \mathrm{KCl}, 1$ $\mathrm{CaCl}_{2}, 3 \mathrm{MgCl}_{2}, 50$ glucose, and $10 \mathrm{HEPES}, \mathrm{pH}$ 7.4. For patch-clamp experiments with rat channels (inside-out configuration), both the external (pipette) and the internal (bath) solutions contained (in mM): 110 $\mathrm{NaCl}, 12 \mathrm{NaOH}, 2$ EDTA, and $10 \mathrm{HEPES}, \mathrm{pH}$ 7.4. For experiments with bovine channels, the external (pipette) solution contained (in mM): 120 $\mathrm{NaCl}, 25 \mathrm{NaOH}, 3 \mathrm{KCl}, 10 \mathrm{EGTA}$, and $10 \mathrm{HEPES}, \mathrm{pH}$ 7.4. The internal (bath) solution contained (in $\mathrm{mM}$ ): $120 \mathrm{KCl}, 25 \mathrm{KOH}, 5 \mathrm{NaCl}, 10$ EGTA, and $10 \mathrm{HEPES}, \mathrm{pH} 7.2$. In the calmodulin experiments, the composition of the internal solution was (in $\mathrm{mm}$ ): $140 \mathrm{KCl}, 10 \mathrm{KOH}, 5 \mathrm{NaCl}, 0.3$ $\mathrm{CaCl}_{2}$, and $10 \mathrm{HEPES}, \mathrm{pH}$ 7.2. Bovine brain calmodulin (Calbiochem, La Jolla, CA) was dissolved at $100 \mu \mathrm{M}$ in distilled water and added to the internal solution containing $0.3 \mathrm{mM} \mathrm{Ca}^{2+}$. Phorbol 12-myristate 13acetate (PMA, 4- $\beta$ isoform; Sigma) and 4- $\alpha$-PMA (Alexis, San Diego, CA) were dissolved in DMSO at $1 \mathrm{mg} / \mathrm{ml}(1.62 \mathrm{~mm})$ and used at a final concentration of $0.5 \mu \mathrm{M}$. Cells were incubated with phorbol ester for 30-60 min at $37^{\circ} \mathrm{C}$, after which patch-clamp experiments were performed for up to $2 \mathrm{hr}$. cAMP and cGMP were obtained from Sigma, and 8-bromo-cAMP (8-Br-cAMP) was obtained from Biolog (Bremen, Germany). All cyclic nucleotide concentrations $>1 \mu \mathrm{M}$ were measured spectrophotometrically $\left(\lambda=260 \mathrm{~nm} ; \epsilon=15,000 \mathrm{~cm}^{2} / \mathrm{mol}\right.$ for all cyclic nucleotides). After current recordings were obtained with a series of cyclic nucleotide concentrations, leak currents (recorded in internal solution without cyclic nucleotides) were subtracted, and a dose-response relation was constructed for each patch by fitting to the data a Hill-type function, $I / I_{\max }=c^{\mathrm{n}} /\left[c^{\mathrm{n}}+\mathrm{K}_{1 / 2}^{n}\right]$, where $I_{\max }$ is the current at saturating concentrations of the ligand, $c$ is the ligand concentration, $n$ is the Hill coefficient, and $\mathrm{K}_{1 / 2}$ is the concentration for half-maximal channel activation. The mean values for $\mathrm{K}_{1 / 2}$ and $n$ from all patches were used to construct the solid lines in the dose-response plots. The figures also show the mean values of $I / I_{\max }$ for each concentration with SDs. In the text, results are given as means \pm SD and numbers of experiments in parentheses. All dose-response relations were obtained at a membrane voltage $\left(V_{\mathrm{m}}\right)$ of $+40 \mathrm{mV}$.

Construction of mutant bovine CNG channels. The truncated mutants MD30 and MP101 were constructed by PCR using pCHOLF102 (Altenhofen et al., 1991) as template and the following primers: a 5' adapter primer [containing an EcoRV restriction site, a consensus sequence for eukaryotic ribosomal-binding site (Kozak, 1984), an initiation codon, and 18 nucleotides following the initiation codon] and a gene-specific $3^{\prime}$ primer. Using suitable restriction sites, the original sequence of pCHOLF102 was replaced by the truncated fragments. The point mutations S93A and S93E were introduced by PCR according to the method of Herlitze and Koenen (1990) using pCHOLF102 as template and oligonucleotides containing the desired nucleotide substitutions. All mutations were verified by sequencing the inserted PCR fragment, and the recombinant cDNA sequences were subcloned into the pcDNAI vector.

\section{RESULTS}

\section{Three isoforms of PKC are expressed in rat olfactory epithelium}

A set of nine different monoclonal antibodies was used to localize PKC immunoreactivity in vertical sections of rat olfactory epithelium. The $\gamma, \delta$, and $\lambda$ isoforms are expressed in the sensory cilia of OSNs (Fig. $1 A, \lambda ; B, \gamma ; D, \delta$ ). Labeling appears as a dark reaction product within the mucociliary layer, which consists of olfactory mucus and the sensory cilia. No staining above background could be found in somata of OSNs, in supporting cells, or in the submucosal tissue. When the primary antibodies were omitted, no immunoreactivity was found in cilia (Fig. 1C). PKC $\delta$ was also found in dendritic knobs of OSNs. In the tissue section shown in Figure $1 E$, most of the cilia were lost during preparation, thus exposing the dendritic knobs, which can be seen at higher magnification. All knobs show strong immunolabeling (arrow). The localization of three PKC isoforms in chemosensory cilia and of $\mathrm{PKC} \delta$ in dendritic knobs suggests a role of these enzymes in chemoelectrical signal transduction. With antibodies raised against the $\operatorname{PKC} \alpha, \beta, \epsilon, \mu$, $\iota$, and $\zeta$ isoforms, no immunolabeling was observed, suggesting that these isoforms are not expressed at all or at levels below detection threshold in OSNs.

\section{Phorbol ester treatment increases ligand sensitivity in olfactory CNG channels}

Both PKC and olfactory CNG channels are expressed specifically in sensory cilia and dendritic knobs of OSNs. We, therefore, looked for effects of increased PKC activity on ligand sensitivity of olfactory CNG channels. For these studies, we used heterologously expressed $\alpha$-homomeric CNG channels from rat (Dhallan et al., 1990) and bovine (Ludwig et al., 1990) olfactory epithelium, which display almost identical properties with regard to activation by cAMP and cGMP. HEK 293 cells expressing olfactory channels were incubated for 30-60 min with 0.5 $\mu \mathrm{M}$ PMA, a phorbol ester that specifically activates most PKC isoforms by substituting for diacylglycerol (Nishizuka, 1986). Cells were then transferred to PMA-free solution, and inside-out patches were taken and exposed to a series of solutions containing various concentrations of cAMP. The $I-V_{\mathrm{m}}$ relations depicted in Figure $2 A$ show macroscopic currents activated by cAMP in a patch from an untreated cell expressing rat $\mathrm{CNG}$ channels. Figure $2 B$ shows $I-V_{\mathrm{m}}$ relations from a cell treated with $0.5 \mu \mathrm{M}$ PMA. The cAMP sensitivity of the channels was strongly increased so that lower cAMP concentrations were sufficient for activation. The dose-response relations in Figure $2 C$ illustrate the shift of current activation to lower cAMP concentrations induced by PMA. The cAMP sensitivity of channels from control cells (circles) was characterized by an activation constant, $\mathrm{K}_{1 / 2}$, of $75 \pm 12 \mu \mathrm{M}$ cAMP, and a Hill coefficient, $n$, of $2.5 \pm 0.4$ (11 patches). These values are in good agreement with earlier reports (Dhallan et al., 1990; Altenhofen et al., 1991; Bradley et al., 1994; Liman and Buck, 1994). Fitting the Hill equation to the data from PMAtreated cells (triangles) yielded $\mathrm{K}_{1 / 2}$ of $12.7 \pm 1.3 \mu \mathrm{M}$ and $n$ of $2.2 \pm 0.16$ (three patches). The PMA-induced increase of cAMP sensitivity persisted in excised patches and did not depend on the presence of $\mathrm{Ca}^{2+}$, indicating that PMA treatment causes a stable, probably covalent modification of the channels.

Olfactory CNG channels display a much higher sensitivity to several analogs of cAMP, including 8-Br-cAMP and 8-chlorophenylthio-cAMP (Frings et al., 1992). We tested whether PMA treatment would also increase 8-Br-cAMP sensitivity and obtained from dose-response relations for control cells a $\mathrm{K}_{1 / 2}$ of $13.3 \pm 1.7 \mu \mathrm{M}$, with $n=2.2 \pm 0.1$ (five patches) and for channels from PMA-treated cells a $\mathrm{K}_{1 / 2}$ of $3.0 \pm 1.12 \mu \mathrm{M}$, with $n=1.70 \pm 0.17$ (five patches) (data not shown). Thus, PMA treatment increased the ligand sensitivity for cAMP and $8-\mathrm{Br}$ cAMP to a similar extent.

Olfactory CNG channels can also be activated by cGMP. In fact, the cGMP sensitivity of $\alpha$-homomeric channels is much 

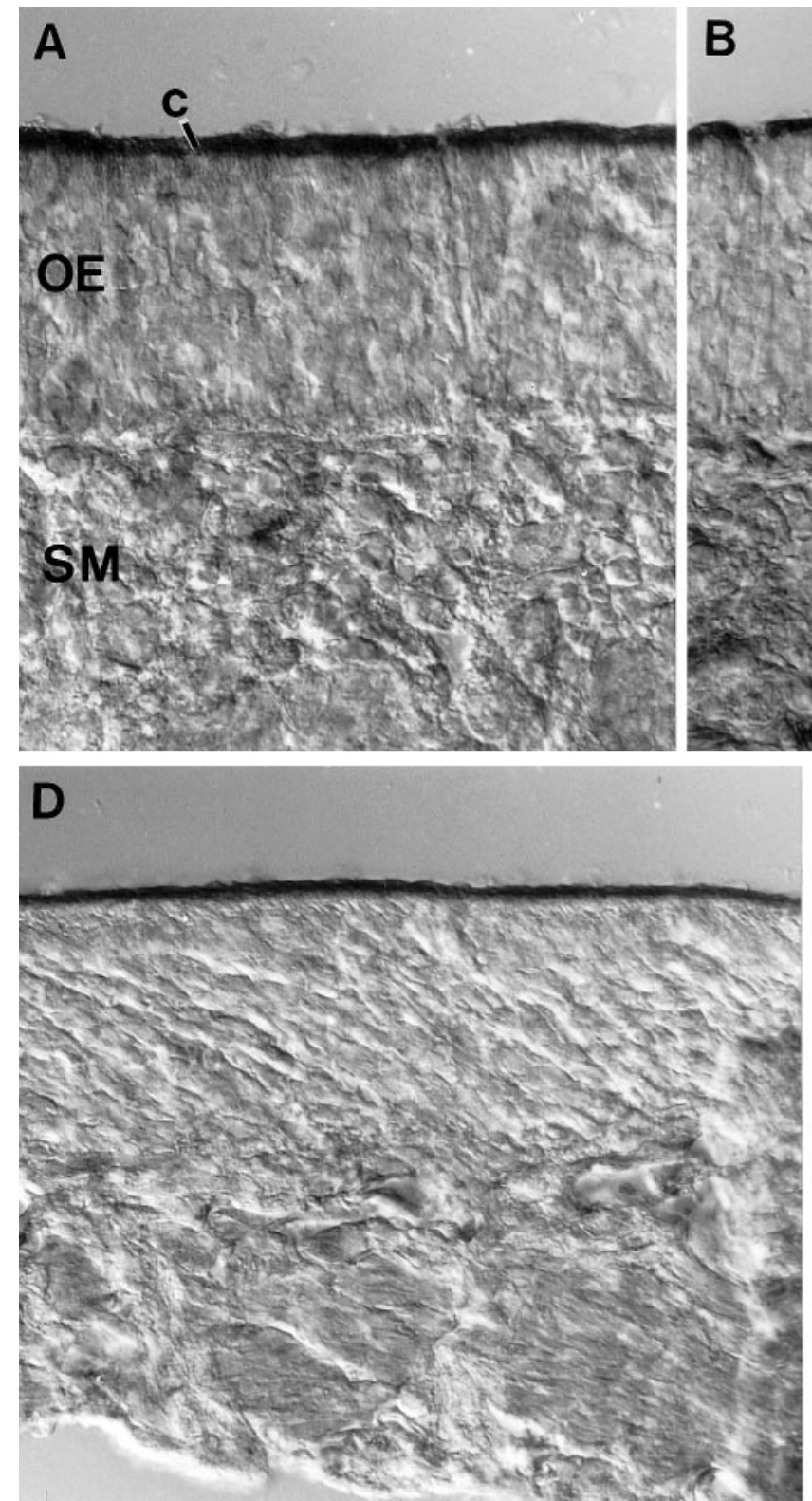
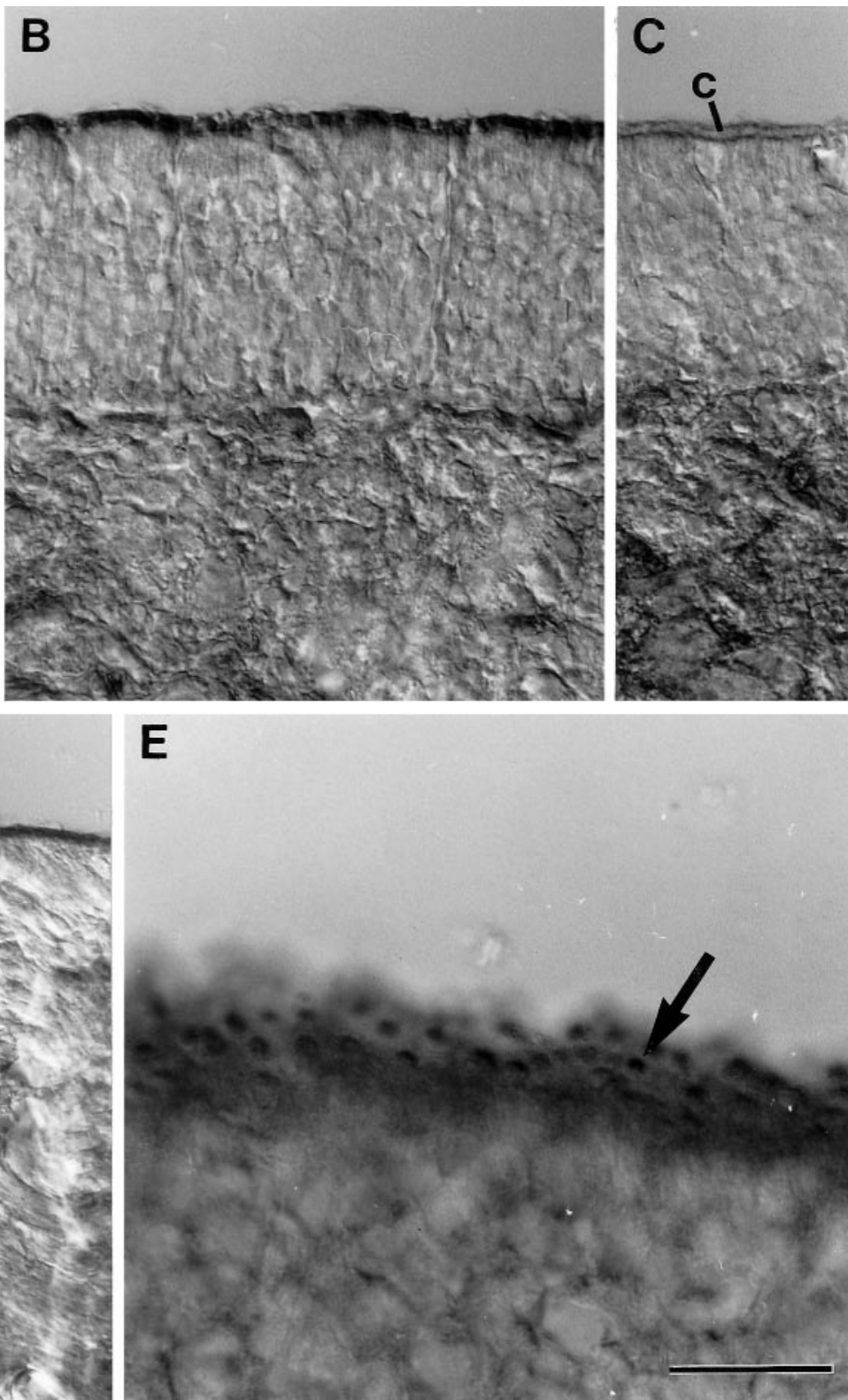

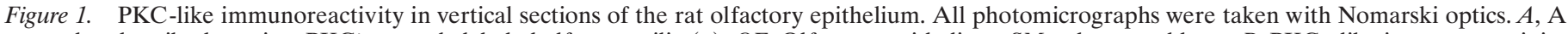

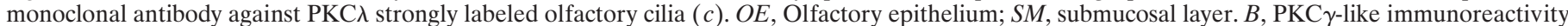

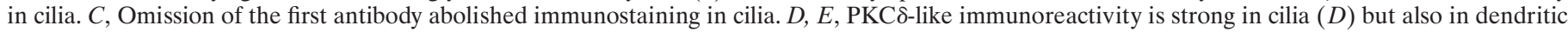

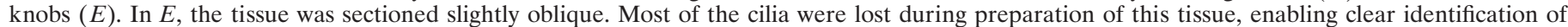
immunolabeled dendritic knobs (arrow). Scale bar: $A-D, 50 \mu \mathrm{m} ; E, 20 \mu \mathrm{m}$.

higher than the sensitivity to cAMP and closely resembles the cGMP sensitivity of the native channel (Dhallan et al., 1990; Altenhofen et al., 1991; Frings et al., 1992). We investigated whether the sensitivity for cGMP is affected by PMA treatment. Figure $3 A$ shows a family of $I-V_{\mathrm{m}}$ relations for cGMP-activated current obtained from a control cell expressing bovine $\mathrm{CNG}$ channels (without PMA), and Figure $3 B$ shows $I-V_{\mathrm{m}}$ relations from a PMA-treated cell. The corresponding dose-response relations in Figure $3 C$ were fitted with $\mathrm{K}_{1 / 2}$ of $1.45 \pm 0.36 \mu \mathrm{M} ; n=$ $2.23 \pm 0.33$ (seven patches) for control currents (filled circles) and with $\mathrm{K}_{1 / 2}$ of $0.30 \pm 0.1 \mu \mathrm{M} ; n=2.03 \pm 0.24$ (18 patches) for currents from PMA-treated cells (triangles), indicating similar effects on the sensitivities for cGMP and cAMP.

To distinguish stimulation of PKC by PMA from unspecific effects of the phorbol ester, we repeated the experiments using 4- $\alpha$-PMA, a PMA isomer that does not activate PKC (VanDuuren et al., 1979). As shown in Figure 3C (open circles), the cGMP sensitivity of the channels was not significantly changed by 4- $\alpha$-PMA $\left(\mathrm{K}_{1 / 2}=1.48 \pm 0.13 \mu \mathrm{M} ; n=2.4 \pm 0.24\right.$; six patches $)$. We, therefore, conclude that the PMA effect on ligand sensitivity is specifically mediated by $\mathrm{PKC}$, and that the activation of endogenous PKC in HEK 293 cells leads to phosphorylation of the olfactory channel protein, resulting in increased sensitivity of the channel to its ligand.

Most patches maintained high ligand sensitivity after patch excision. However, 3 of 18 patches showed a partial or complete reset of cGMP sensitivity to control values 15-25 min after excision (data not shown). In one patch, the current activation 
A

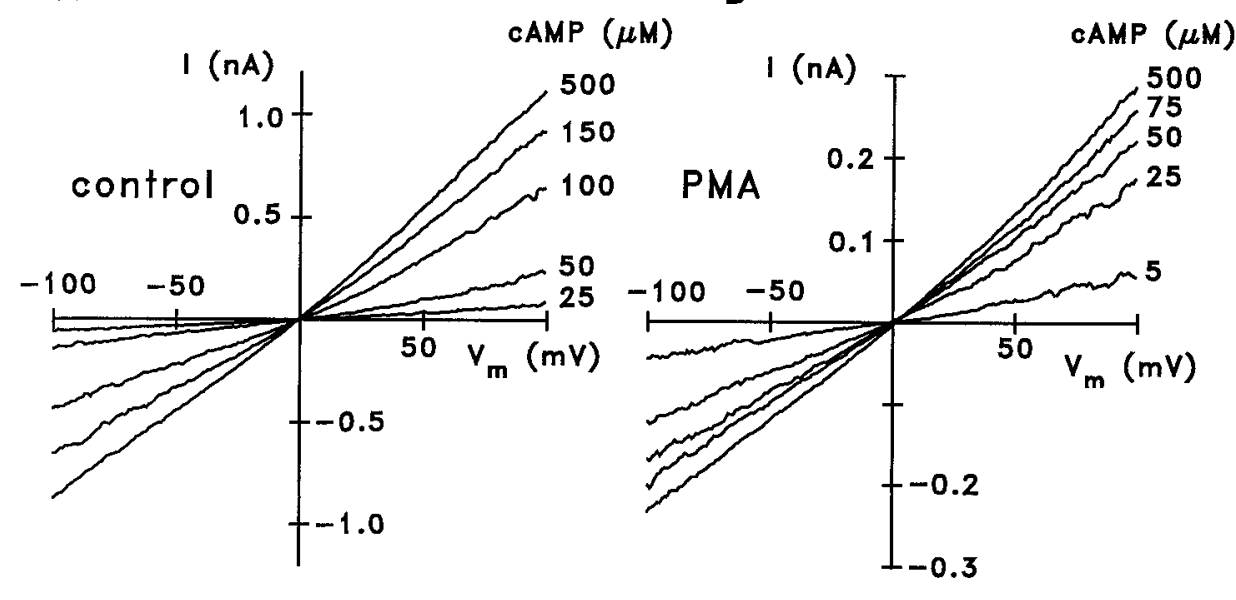

C

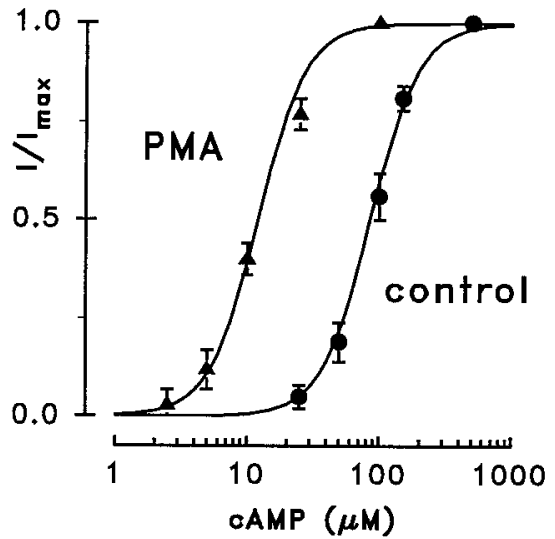

Figure 2. Modulation of cAMP sensitivity of rat $\alpha$-homomeric CNG channels by treatment with $0.5 \mu \mathrm{M}$ PMA. $A, I-V_{\mathrm{m}}$ relations recorded from an inside-out patch from an untreated HEK 293 cell expressing rat olfactory channels. The respective cAMP concentrations are indicated at each trace. $B$, $I-V_{\mathrm{m}}$ relations obtained from a cell after treatment with $0.5 \mu \mathrm{M}$ PMA, showing increased cAMP sensitivity of CNG channels. $C$, Dose-response relations for current activation by cAMP at $V_{\mathrm{m}}=+40 \mathrm{mV}$ in control (circles) and PMA-treated (triangles) cells. Solid lines were constructed by fitting to the normalized current a Hill-type function, as described in Materials and Methods. Fitting parameters were $K_{1 / 2}=75 \pm 12 \mu \mathrm{M} ; n=2.5 \pm 0.4$ (11 patches) for control and $K_{1 / 2}=12.7 \pm 1.3 \mu \mathrm{M} ; n=2.2 \pm 0.16$ ( 3 patches) for PMA-treated channels.

shortly after excision from a PMA-treated cell was characterized by $I_{\max }=745 \mathrm{pA}, \mathrm{K}_{1 / 2}=0.3 \mu \mathrm{M}$, and $n=2.2\left(V_{\mathrm{m}}=+40 \mathrm{mV}\right)$. Twenty-five minutes later, $I_{\max }$ was $720 \mathrm{pA}$, whereas $\mathrm{K}_{1 / 2}$ was increased to $\sim 2 \mu \mathrm{M}$, indicating that the ligand sensitivity had been reset to the control value. We cannot explain this observation, but, possibly, some phosphatase activity was preserved in the excised patch configuration, sufficient to dephosphorylate the channels in these patches.

To test for possible effects of phosphorylation on channel conductance in cGMP-activated channels, we obtained singlechannel recordings from control cells (Fig. 3D) and from PMAtreated cells (Fig. $3 E$ ). The recordings from control cells were obtained at $2 \mu \mathrm{M}$ cGMP and the indicated values of $V_{\mathrm{m}}$. The voltage dependence of single-channel current derived from these recordings is shown in Figure $3 F$ (circles) and indicates a conductance of $36.8 \pm 2.7 \mathrm{pS}$ (11 patches) for control channels. Singlechannel traces from PMA-treated cells were recorded at $0.5 \mu \mathrm{M}$ cGMP to obtain a comparable open probability of the channels. The conductance of phosphorylated channels $(38.2 \pm 3.2 \mathrm{pS}$; four patches) is not significantly different from the value observed in untreated channels (Fig. 3F, triangles). Thus, phosphorylation enhances the ligand sensitivity of olfactory CNG channels by increasing their open probability without affecting their conductance.

\section{The PKC effect is mediated by a single amino acid residue}

Recently it was shown (Liu et al., 1994) that the ligand sensitivity of olfactory CNG channels is controlled by a stretch of amino acid residues within the cytoplasmic N-terminal region of the $\alpha$-subunit (Fig. 4A, CaM, FR). This domain exhibits a high degree of sequence homology among all cloned olfactory $\alpha$-subunits (Fig. 4B). It contains a binding site for calmodulin (Fig. 4, CaM) and a flanking region (Fig. 4,FR) that extends in the C-terminal direction from the calmodulin-binding site. Both regions control the ligand sensitivity of the channel. If either of the two regions is deleted, the ligand sensitivity is reduced. Binding of calmodulin causes a similar decrease of ligand sensitivity as deletion of either of the two regions (Chen and Yau, 1994; Liu et al., 1994).

Because this domain is crucial for modulating the ligand sensitivity, we investigated its involvement in the PKC effect. We first constructed a truncated version of the bovine olfactory $\alpha$-subunit, which did not contain the calmodulin-binding site and the adjacent 21 amino acid residues of the flanking region. This construct, MP101 (truncated until Gly ${ }^{100}$ ), was expressed in HEK 293 cells and subjected to the same PMA treatment as the wild-type channels. In accordance with results obtained in the rat $\alpha$-subunit (Liu et al., 1994), MP101 displayed a reduced cGMP sensitivity $\left(\mathrm{K}_{1 / 2}=8.2 \pm 1.07 \mu \mathrm{M} ; n=2.76 \pm 0.29\right.$; seven patches) (Fig. $5 A$, circles). The cGMP sensitivity of MP101 did not increase after treatment with PMA (triangles) but was slightly reduced $\left(\mathrm{K}_{1 / 2}=\right.$ $11.9 \pm 2.2 \mu \mathrm{M} ; n=2.42 \pm 0.32$; five patches). Figure $5 B$ shows that the truncated channel is not sensitive to calmodulin. As control experiments, inside-out patches were perfused with internal solution containing $0.3 \mathrm{mM} \mathrm{Ca}^{2+}$ but no calmodulin (circles). The $\mathrm{K}_{1 / 2}$ was $14.6 \pm 3.1 \mu \mathrm{M}$, with $n=2.2 \pm 0.32$ (five patches) under control conditions. (All olfactory channels tested show a slightly reduced ligand sensitivity in the presence of elevated $\left[\mathrm{Ca}^{2+}\right]_{i}$; cf. Table 1.) After exposure of the patches to $0.5 \mu \mathrm{M}$ calmodulin for $3 \mathrm{~min}$, the cGMP sensitivity was virtually unchanged $\left(\mathrm{K}_{1 / 2}=15.5 \pm 3.6 \mu \mathrm{M} ; n=1.88 \pm 0.13\right.$; five patches $)$ (Fig. 5B, triangles). Under the same experimental protocol, calmodulin caused a sevenfold increase of $\mathrm{K}_{1 / 2}$ in the wild-type channel (see below). Thus, both PKC-mediated increase and calmodulin-induced decrease of ligand sensitivity are absent in the truncated channel MP101. A second truncated channel polypeptide, MD30, which contained both the calmodulinbinding site and the flanking region (truncated until Lys ${ }^{29}$ ) showed responses to calmodulin and to PMA treatment similar to the wild-type channels (Table 1). These experiments show that the PKC-induced modulation of ligand sensitivity in olfactory channels involves a segment of the $\mathrm{N}$-terminal region between Lys $^{29}$ and Gly ${ }^{100}$. 
A

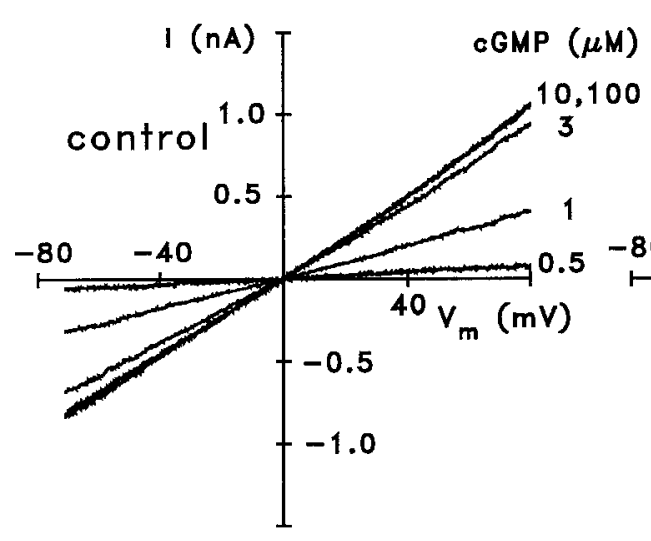

D
B

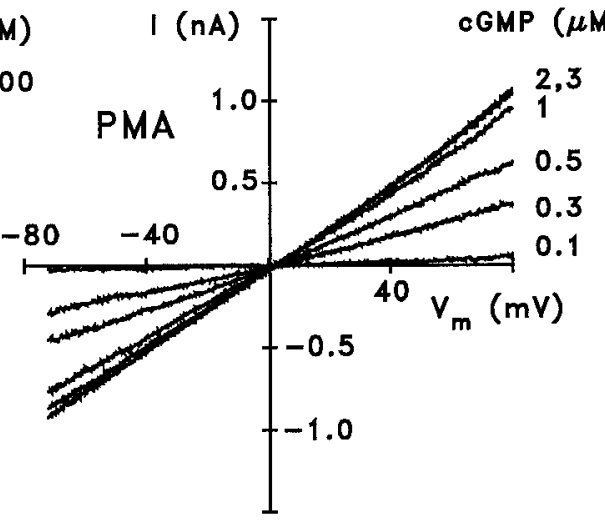

$E$
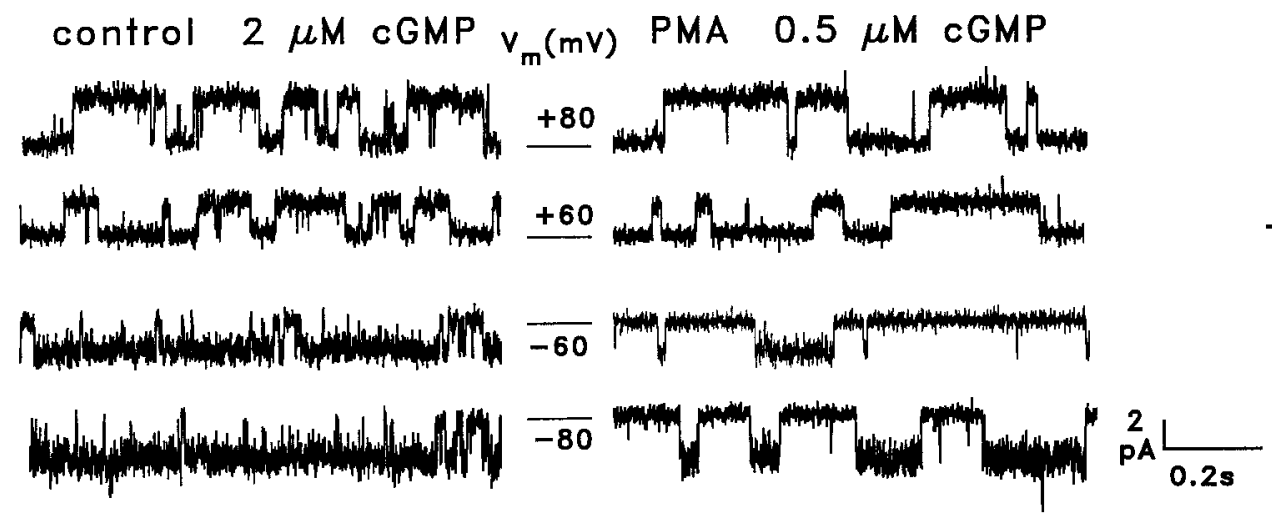

C

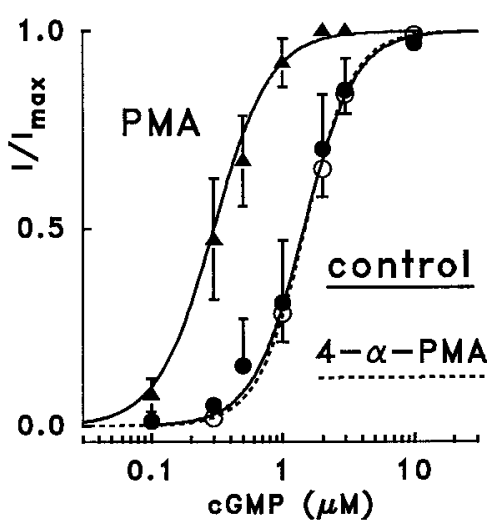

F

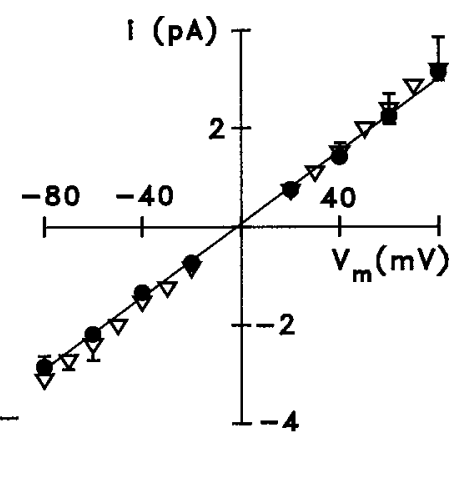

Figure 3. Increase of cGMP sensitivity in bovine $\alpha$-homomeric CNG channels after PMA treatment. $A, I-V_{\mathrm{m}}$ relations recorded from an inside-out patch of untreated HEK 293 cells expressing bovine olfactory CNG channel $\alpha$-subunits. $B, I-V_{\mathrm{m}}$ relations from a patch after treatment of the cell with PMA showing activation of channel current by lower cGMP concentrations. $C$, Dose-response relations for channel activation by cGMP obtained from patches without ( filled circles) and with (triangles) PMA treatment $\left(V_{\mathrm{m}}=+40 \mathrm{mV}\right)$. Fitting parameters are given in Table 1 . The PMA isomer 4- $\alpha$-PMA, which does not activate PKC, does not modulate sensitivity in olfactory CNG channels (open circles). D, Single-channel currents recorded from an $\alpha$-homomeric olfactory CNG channel. The recordings were obtained from an inside-out patch of an untreated cell with $2 \mu \mathrm{M}$ cGMP, at the indicated values of $V_{\mathrm{m}}$. Sample rate, $3 \mathrm{kHz}$; low-pass filter, $1 \mathrm{kHz}$. E, Single-channel recordings from a PMA-treated cell with $0.5 \mu \mathrm{M}$ cGMP. $F$, Voltage dependence of the single-channel current of control (circles) and PMA-treated (triangles) channels. The slope conductances are $36.8 \pm 2.7 \mathrm{pS}$ (11 patches) for control, and $38.2 \pm 3.2 \mathrm{pS}$ (4 patches) for PMA-treated channels.

The flanking region (Fig. 4, FR) contains a consensus phosphorylation sequence ( $\mathrm{Arg}^{90}-\mathrm{Ser}^{93}$ in the bovine channel) that may form a recognition site for PKC (Pearson and Kemp, 1991). To test whether phosphorylation of $\mathrm{Ser}^{93}$ mediates the PMA effect on ligand sensitivity, we replaced $\operatorname{Ser}^{93}$ with alanine (mutant S93A) and measured the cGMP sensitivity with and without PMA treatment (Fig. 5C). Under control conditions (circles), S93A showed a cGMP sensitivity similar to that of the wild type $\left(\mathrm{K}_{1 / 2}=1.93 \pm 0.15 \mu \mathrm{M} ; n=2.03 \pm 0.35\right.$; five patches $)$. After PMA treatment (triangles), the cGMP sensitivity was not changed significantly $\left(\mathrm{K}_{1 / 2}=2.2 \pm 0.56 \mu \mathrm{M} ; n=2.06 \pm 0.27\right.$; six patches $)$. This lack of PMA effect in S93A strongly suggests that a PKCmediated phosphorylation of $\mathrm{Ser}^{93}$ is responsible for the increase of ligand sensitivity.

The effect of phosphorylation can sometimes be mimicked by replacing the amino acid residue serving as the kinase substrate by glutamate or aspartate. These residues can substitute for the negative charge otherwise provided by phosphate and, thereby, can produce the phenotype corresponding to the phosphorylated state of the protein (e.g., Smith and Goldin, 1996). We generated an S93E mutant of the olfactory CNG channel to test whether replacement of $\operatorname{Ser}^{93}$ by a glutamate residue would produce a channel with constitutively increased cGMP sensitivity. However, S93E displayed the same properties as S93A (Table 1). Thus, the modulation of ligand sensitivity by phosphorylation of $\mathrm{Ser}^{93}$ cannot be explained by the introduction of a negative charge into the region flanking the calmodulin-binding site.

\section{Calmodulin-induced modulation is preserved in the phosphorylated channel}

We examined whether the PKC-mediated increase of ligand sensitivity interferes with the antagonistic modulation of the channel by calmodulin. Inside-out patches from transfected cells were first washed in $\mathrm{Ca}^{2+}$-free solution to remove any endogenous $\mathrm{Ca}^{2+}$-binding proteins of the HEK 293 cells. To obtain dose-response relations for channel activation under control conditions, $I-V_{\mathrm{m}}$ curves were first recorded in internal solution containing $0.3 \mathrm{mM} \mathrm{Ca}{ }^{2+}$ and various concentrations of cGMP. Patches were then exposed for 3 min to the same solution containing $0.5 \mu \mathrm{M}$ calmodulin and no cGMP to saturate the channels with calmodulin. Subsequently, $I-V_{\mathrm{m}}$ relations were again recorded at increasing cGMP concentration in the presence of 0.3 
A

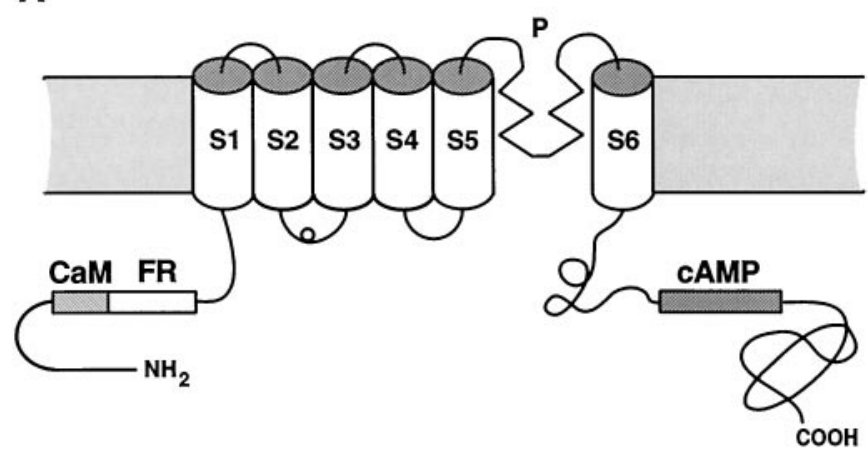

B

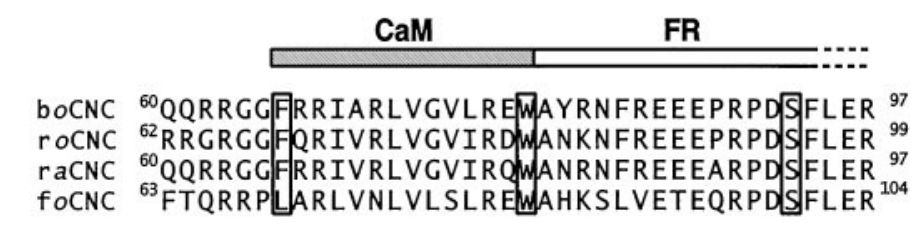

Figure 4. A, Schematic representation of the transmembrane topology of the olfactory CNG channel $\alpha$-subunit according to Henn et al. (1995); $S 1-S 6$, Transmembrane regions; $P$, pore region. The N-terminus harbors a regulatory domain consisting of a calmodulin-binding site $\left(\mathrm{CaM}\right.$; $\mathrm{Phe}^{66}$ $\operatorname{Trp}^{79}$ in boCNC) and its flanking region $(F R)$. The border of the $F R$ region toward the $S 1$ segment is not known. The $\mathrm{C}$-terminus contains the cyclic nucleotide-binding site ( $A M M P$; Gly ${ }^{461}-\mathrm{Leu}^{578}$ in boCNC). $B$, Alignment of the amino acid sequence of the $\mathrm{NH}_{2}$-terminal regulatory domain of bovine olfactory $\alpha$-subunits (boCNC; Ludwig et al., 1990) with the corresponding domains of rat (roCNC; Dhallan et al., 1990), rabbit ( $\mathrm{r} a \mathrm{CNC}$; Biel et al., 1993), and catfish (foCNC; Goulding et al., 1992). Boxed amino acid residues are the hydrophobic residues that represent positions 1 and 14 of the calmodulin-binding site, as well as a serine residue ( $\mathrm{Ser}^{93}$ in boCNC) that is part of a consensus site for protein phosphorylation (RXXS).

mM $\mathrm{Ca}^{2+}$ (Fig. 6A). The dose-response relations in Figure $6 B$ demonstrate a calmodulin-induced shift of cGMP sensitivity from the control $\left(\mathrm{K}_{1 / 2}=1.76 \pm 0.26 \mu \mathrm{M} ; n=2.47 \pm 0.38\right.$; seven patches) (Fig. $6 A$, circles) to the calmodulin-bound state of the channel $\left(\mathrm{K}_{1 / 2}=12.0 \pm 2.8 \mu \mathrm{M} ; n=2.8 \pm 0.9 ; 14\right.$ patches) (Fig. $6 A$, triangles). A similar calmodulin-induced increase of $\mathrm{K}_{1 / 2}$ was reported earlier for $\alpha$-homomeric channels of the rat (Chen and Yau, 1994). The calmodulin effect was readily reversible; washing the patch for $2-5 \mathrm{sec}$ in $\mathrm{Ca}^{2+}$-free internal solution caused dissociation of calmodulin from the channel and the consequent reset of control cGMP sensitivity (data not shown). When patches from PMA-treated cells were subjected to the same calmodulin treatment, we observed a strong decrease of the cGMP sensitivity; recordings from phosphorylated channels without calmodulin (Fig. $6 C$, circles) yielded a $\mathrm{K}_{1 / 2}$ of $0.35 \pm 0.03 \mu \mathrm{M}$ and $n=1.85 \pm 0.19$ (six patches). After exposure to calmodulin (triangles), activation was characterized by a $\mathrm{K}_{1 / 2}$ of $14.4 \pm 2.3 \mu \mathrm{M}$ and $n=2.35 \pm 0.7$ (six patches). $\mathrm{K}_{1 / 2}$ was reversed to the control value by brief exposure to $\mathrm{Ca}^{2+}$-free solution. These results show that the PKC-mediated phosphorylation of $\mathrm{Ser}^{93}$ induces an increase of ligand sensitivity only if the calmodulin-binding site is not occupied. They also demonstrate that the dynamic range of the calmodulin-dependent modulation is much larger when Ser ${ }^{93}$ is phosphorylated; the value of $\mathrm{K}_{1 / 2}$ increases during binding of calmodulin 40 -fold in phosphorylated channels but only sevenfold in channels from untreated cells. Mutation of $\mathrm{Ser}^{93}$ did not change the sensitivity of the channel for calmodulin; application of calmodulin to mutant $\mathrm{S} 93 \mathrm{~A}$ reduced the cGMP sensitivity from control $\left(\mathrm{K}_{1 / 2}=2.19 \pm 0.48 \mu \mathrm{M} ; n=2.34 \pm 0.19\right.$; seven patches $)$ to the calmodulin-bound state $\left(\mathrm{K}_{1 / 2}=17.3 \pm 6.1 \mu \mathrm{M}\right.$; $n=1.8 \pm 0.47$; five patches) by a similar extent as observed with wild-type channels (eightfold).

\section{DISCUSSION}

Recent results from several groups indicate that the ligand sensitivity of olfactory $\mathrm{CNG}$ channels can be regulated through binding of calmodulin or other cytosolic components. During odorant stimulation, olfactory channels can carry substantial $\mathrm{Ca}^{2+}$ currents into the cilia (Frings et al., 1995), causing the ciliary $\mathrm{Ca}^{2+}$ concentration to increase (Lowe and Gold, 1993b; Tareilus et al., 1995; Leinders-Zufall et al., 1997). At elevated ciliary $\mathrm{Ca}^{2+}$ concentration, calmodulin and, possibly, other $\mathrm{Ca}^{2+}$-binding proteins present in OSN (Bastianelli et al., 1995; Balasubramanian et al., 1996; Boekhoff et al., 1997) reduce ligand sensitivity, promote closure of the channels, and terminate the excitatory phase of the odorant response (Kurahashi and Menini, 1997).

The purpose of the present study was to investigate a second regulatory mechanism of ligand sensitivity in olfactory $\mathrm{CNG}$ channels: phosphorylation of the $\alpha$-subunit by PKC. There is ample evidence for an involvement of PKC in olfactory signal transduction. PKC was first detected in ciliary preparations of amphibian OSNs by Anholt et al. (1987), and, more recently, PKC was shown to participate in adaptation by inactivating odorant receptors (Boekhoff and Breer, 1992; Boekhoff et al., 1992). Moreover, activation of PKC appears to increase the odorantstimulated cAMP synthesis in amphibian olfactory epithelium (Frings, 1993), suggesting a modulatory role of this enzyme also in the excitation of the neuron.

We have shown that the $\gamma$-, $\delta$-, and $\lambda$ isoforms of PKC are expressed in the sensory cilia of rat OSNs. This set of enzymes covers the entire range of known PKC isoforms (for review, see Dekker, 1997). The $\gamma$ isoform belongs to the group of "classic" PKCs that are $\mathrm{Ca}^{2+}$-dependent, activated by diacylglycerol, and exhibit comparably low substrate specificity. The $\delta$ isoform is a "novel" and the $\lambda$ isoform an "atypical" PKC, both characterized by $\mathrm{Ca}^{2+}$-independent activity and a more restricted substrate profile. Interestingly, $\mathrm{PKC} \lambda$ is not sensitive to diacylglycerol or phorbol esters and may be activated by arachidonic acid or phosphatidylinositol 3,4,5-trisphosphate (Akimoto et al., 1994). Regulation of the three PKC isoforms in OSNs as well as their cellular targets has yet to be identified. Our data suggest that the olfactory CNG channel could be the target of PKC-mediated phosphorylation. Activation of PKC in HEK 293 cells leads to an increase of ligand sensitivity of heterologously expressed $\alpha$-homomeric channels. This effect is brought about by phosphorylation of $\mathrm{Ser}^{93}$, an amino acid residue situated in the intracellular $\mathrm{N}$-terminal region of the channel polypeptide. $\mathrm{Ser}^{93}$ is located near the calmodulin-binding site. But while calmodulin binding decreases ligand sensitivity, phosphorylation of $\operatorname{Ser}^{93}$ has the opposite effect. Thus, the regulatory domain within the $\mathrm{N}$-terminal region (consisting of the calmodulin-binding site and the flanking region that contains $\mathrm{Ser}^{93}$ ) can serve two opposing functions. Interestingly, binding of calmodulin reduces the ligand sensitivity regardless of the phosphorylation state of Ser ${ }^{93}$, suggesting that the conformational transition induced by binding of calmodulin is the main determinant of sensitivity. On the other 
A

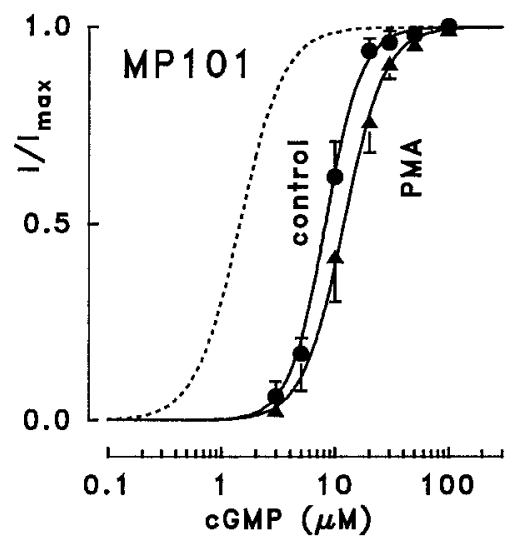

B

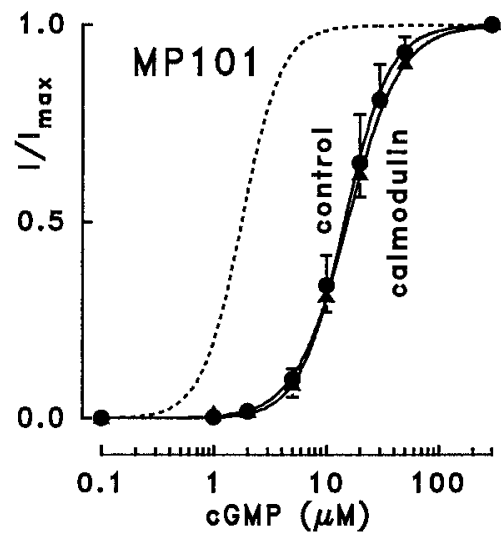

$\mathrm{C}$

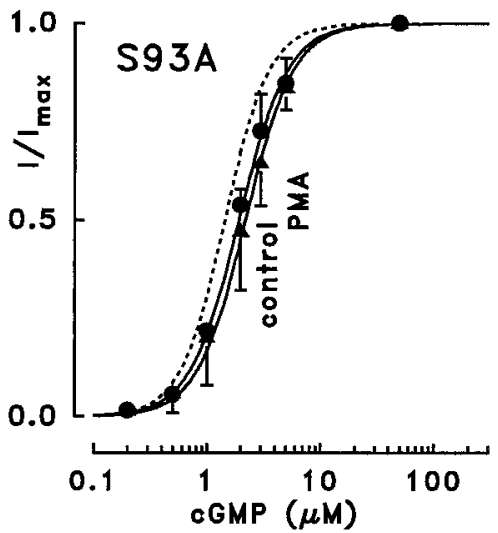

Figure 5. Localization of the amino acid residue that mediates the PMA-induced effect on ligand sensitivity. $A$, Loss of PMA effect in the mutant channel MP101 (truncated N-terminally until $\mathrm{Gly}^{100}$ ). Dose-response relations were obtained at $V_{\mathrm{m}}=+40 \mathrm{mV}$ in Ca ${ }^{2+}$-free internal solution from cells expressing mutant channels without (circles) and with (triangles) PMA treatment. The phorbol ester treatment did not increase but slightly decreased the cGMP sensitivity of the channel. For comparison, a dose-response relation of the untreated wild-type channel is shown (dotted line). B, Loss of calmodulin sensitivity in MP101. Dose-response relations in the presence of internal solution containing $0.3 \mathrm{~mm} \mathrm{Ca}^{2+}$ before (circles) and after (triangles) exposure of patches to $0.5 \mu \mathrm{M}$ calmodulin for $3 \mathrm{~min}$. The same protocol causes a sevenfold increase of $K_{1 / 2}$ in wild-type channels (see Fig. 6). The dotted line shows the dose-response relation of the wild-type channel in internal solution containing $0.3 \mathrm{mM} \mathrm{Ca}^{2+}$ without calmodulin. $C$, Replacement of $\mathrm{Ser}^{93}$ abolishes the effect of PMA. Dose-response relations of S93A mutant channels without (circles) and with (triangles) PMA treatment show that the mutant does not respond to activation of PKC, whereas its cGMP sensitivity under control conditions is only slightly reduced with respect to the wild type (dotted line).

hand, deleting only the flanking region renders the channel insensitive to calmodulin (Liu et al., 1994), although calmodulin presumably still binds. It thus appears that both parts of this regulatory domain are involved in channel opening, and that both can contribute to the determination of ligand sensitivity.

Table 1. cGMP sensitivity of wild-type (WT) and mutant bovine olfactory CNG channel $\alpha$-subunits

\begin{tabular}{|c|c|c|c|c|}
\hline & \multicolumn{2}{|l|}{$\mathrm{Ca}^{2+}$-free } & \multicolumn{2}{|c|}{$0.3 \mathrm{mM} \mathrm{Ca}^{2+}$} \\
\hline & Control & +PMA & Control & +Calmodulin \\
\hline \multicolumn{5}{|l|}{ WT } \\
\hline $\mathrm{K}_{1 / 2}$ & $1.45 \pm 0.36$ & $0.30 \pm 0.10$ & $1.76 \pm 0.26$ & $12.0 \pm 2.8$ \\
\hline$n$ & $2.23 \pm 0.33$ & $2.03 \pm 0.24$ & $2.47 \pm 0.38$ & $2.80 \pm 0.90$ \\
\hline Exp & 7 & 18 & 7 & 14 \\
\hline \multicolumn{5}{|l|}{ MP101 } \\
\hline $\mathrm{K}_{1 / 2}$ & $8.20 \pm 1.07$ & $11.9 \pm 2.2$ & $14.6 \pm 3.10$ & $15.5 \pm 3.60$ \\
\hline$n$ & $2.76 \pm 0.29$ & $2.42 \pm 0.32$ & $2.20 \pm 0.32$ & $1.88 \pm 0.13$ \\
\hline Exp & 7 & 5 & 5 & 5 \\
\hline \multicolumn{5}{|l|}{ MD30 } \\
\hline$K_{1 / 2}$ & $1.48 \pm 0.20$ & $0.35 \pm 0.03$ & $1.62 \pm 0.24$ & $21.8 \pm 4.80$ \\
\hline$n$ & $2.15 \pm 0.43$ & $1.85 \pm 0.15$ & $2.01 \pm 0.12$ & $2.20 \pm 0.17$ \\
\hline Exp & 6 & 6 & 5 & 7 \\
\hline \multicolumn{5}{|l|}{ S93A } \\
\hline$K_{1 / 2}$ & $1.93 \pm 0.15$ & $2.20 \pm 0.56$ & $2.19 \pm 0.48$ & $17.3 \pm 6.10$ \\
\hline$n$ & $2.03 \pm 0.35$ & $2.06 \pm 0.27$ & $2.34 \pm 0.19$ & $1.80 \pm 0.47$ \\
\hline Exp & 5 & 6 & 7 & 5 \\
\hline \multicolumn{5}{|l|}{ S93E } \\
\hline$K_{1 / 2}$ & $2.11 \pm 0.48$ & $2.27 \pm 0.57$ & & \\
\hline$n$ & $1.97 \pm 0.24$ & $1.73 \pm 0.12$ & & \\
\hline Exp & 7 & 4 & & \\
\hline
\end{tabular}

Concentration for half-maximal activation $\left(K_{1 / 2}\right)$, Hill coefficient $(n)$, and numbers of experiments (Exp) for channel activation by cGMP at $V_{\mathrm{m}}=+40 \mathrm{mV}$. Obtained from inside-out recordings in either $\mathrm{Ca}^{2+}$-free internal solution (PMA experiments) or with $0.3 \mathrm{~mm}$ internal $\mathrm{Ca}^{2+}$ (calmodulin experiments).
These findings give further evidence for a critical allosteric role of the N-terminal region in the gating of CNG channels, which was demonstrated previously in mutagenesis studies (Goulding et al., 1994; Tibbs et al., 1997). It appears that the N-terminus determines the ease with which the binding of cyclic nucleotides to the $\mathrm{C}$-terminus is converted into channel opening. Most recently, Varnum and Zagotta (1997) showed that the $\mathrm{N}$ - and $\mathrm{C}$ - termini of olfactory CNG channels interact. The calmodulinbinding site and part of the flanking region in the $\mathrm{N}$-terminus bind to an identified domain in the $\mathrm{C}$-terminus. This interdomain interaction facilitates channel opening, and it may be that phosphorylation of $\operatorname{Ser}^{93}$ increases gating efficacy of the channel by stabilizing this interdomain complex.

\section{Does phosphorylation modulate the native olfactory CNG channel?}

Phosphorylation of Ser ${ }^{93}$ profoundly affects the ligand sensitivity of the $\alpha$-homomeric channel. However, the native olfactory CNG channel most probably consists of at least two different subunits, and we do not know whether modulation by PKC is conserved in the heteromeric protein. Direct evidence can only be obtained from intact OSNs or, alternatively, from heterologously expressed CNG channels with correct subunit composition.

To measure ligand sensitivity of native channels, OSNs must be isolated from the olfactory epithelium, and patch-clamp recordings can then be obtained from the membrane of dendritic knobs (Frings et al., 1992; Balasubramanian et al., 1995, 1996). Because of the small size of sensory cilia (diameter, $0.2 \mu \mathrm{m}$ ), ciliary CNG channels are not accessible for such recordings. We measured the cAMP sensitivity of native rat channels in membrane patches from dendritic knobs. We obtained a $\mathrm{K}_{1 / 2}$ of $4.13 \pm 1.9 \mu \mathrm{M} ; n=$ $1.65 \pm 0.1$ (four patches) for control channels and a $\mathrm{K}_{1 / 2}$ of $3.50 \pm$ $0.9 \mu \mathrm{M} ; n=1.50 \pm 0.2$ (eight patches) for channels measured after OSNs had been treated with $1 \mu \mathrm{M}$ PMA and $0.6 \mu \mathrm{M}$ okadaic acid (to inhibit phosphatase activity) before, during, and after the 


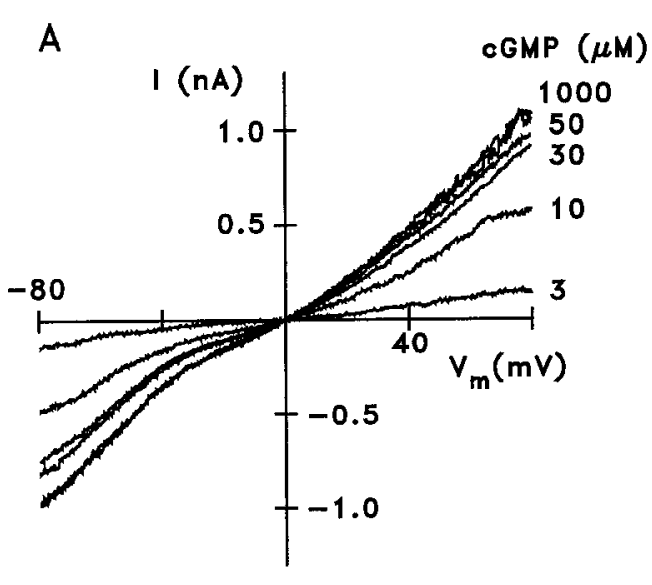

B

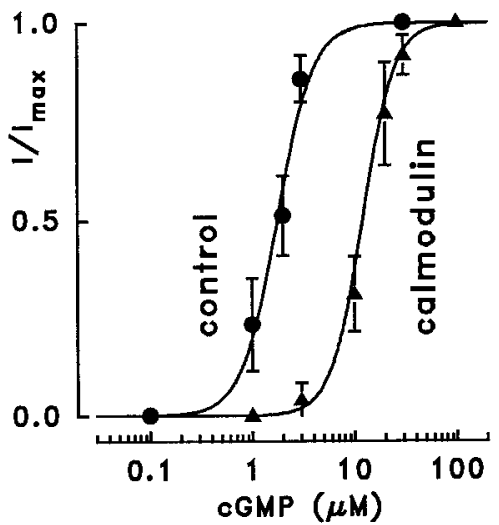

C

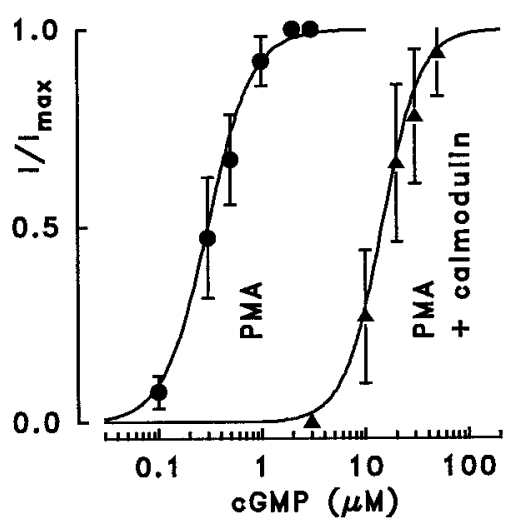

Figure 6. The calmodulin effect on ligand sensitivity is not counteracted by PKC-mediated phosphorylation. $A, I-V_{\mathrm{m}}$ relations recorded from an inside-out patch of a cell expressing wild-type channels after exposure to $0.5 \mu \mathrm{M}$ calmodulin for $3 \mathrm{~min}$. The patch was held in internal solution containing $0.3 \mathrm{mM} \mathrm{Ca}^{2+}$, and the indicated concentrations of cGMP were applied. Before calmodulin application, and also after removal of calmodulin in $\mathrm{Ca}^{2+}$-free internal solution, the patch showed almost maximal channel activation by $3 \mu \mathrm{M}$ cGMP (data not shown). The nonlinear shape of the $I-V_{\mathrm{m}}$ relations results from voltage-dependent channel blockage by internal $\mathrm{Ca}^{2+} . B$. Dose-response relations for channel activation obtained from untreated wild-type channels before (circles) and after (triangles) exposure to calmodulin. Both relations were derived at $V_{\mathrm{m}}=+40 \mathrm{mV}$ with internal solution containing 0.3 $\mathrm{mM} \mathrm{Ca}{ }^{2+} . C$, Calmodulin-induced reduction of cGMP sensitivity in wild-type channels after PMA treatment. Inside-out patches from PMA-treated cells were exposed to internal solution containing $0.3 \mathrm{mM} \mathrm{Ca}^{2+}$ and various concentrations of cGMP before (circles) and after (triangles) incubation with $0.5 \mu \mathrm{M}$ calmodulin. The dose-response relations show a 40 -fold increase of $K_{1 / 2}$ for channel activation caused by the exposure of the phosphorylated channels to calmodulin.

dissociation procedure (data not shown). Thus, PMA treatment does not significantly increase ligand sensitivity in CNG channels from dendritic knobs of isolated OSNs. However, several aspects have to be considered for the interpretation of this observation: (1) OSNs may be damaged during dissociation, may lose the ability to phosphorylate the channel, or may allow dephosphorylation during cell isolation; (2) channels in dendritic knobs analyzed here are colocalized only with $\mathrm{PKC} \delta$, which may not recognize $\operatorname{Ser}^{93}$ as a substrate, whereas $\operatorname{Ser}^{93}$ of channels expressed in the ciliary membrane could be phosphorylated by the $\gamma$ and $\lambda$ isoforms; (3) phosphorylation of native channels may be specifically mediated by $\mathrm{PKC} \lambda$, which is not activated by phorbol esters; (4) channels may be constitutively phosphorylated so that activation of PKC does not lead to a change of ligand sensitivity; and (5) additional channel subunits may obstruct phosphorylation of the $\alpha$-subunit or may prevent the change of ligand sensitivity in the phosphorylated channel. Because these problems cannot be investigated in isolated OSNs, the most promising approach is the heterologous coexpression of different channel subunits and phosphorylation experiments with channels of the correct subunit composition. This will probably be feasible in the near future, because the subunits that contribute to the native olfactory channel of the rat have been identified recently (F. Sesti, W. Bönigk, J. Bradley, F. Müller, S. Frings, and U. B. Kaupp, unpublished data).

Indirect evidence supporting a role of phosphorylation in the modulation of ligand sensitivity comes from studies of rod photoreceptor CNG channels. Gordon et al. (1992) have demonstrated that the cGMP sensitivity of CNG channels in membrane patches excised from the outer segment of isolated photoreceptors can be changed by application of protein phosphatases. This observation suggests that CNG channels in these cells are phosphorylated, and that the phosphorylation state determines ligand sensitivity. Thus, native photoreceptor $\mathrm{CNG}$ channels seem to be modulated by phosphorylation much like other ligand-gated chan- nels. Modulation by protein phosphorylation is well documented for receptors of acetylcholine, GABA, glycine, and glutamate (for review, see Swope et al., 1992). To understand the role of phosphorylation in the regulation of olfactory channels, it will be crucial to identify physiological activators of PKC in OSNs. Promising candidates may be agents that activate phospholipase $\mathrm{C}$, such as neurotransmitters (Frings, 1993) and certain types of odorants (Boekhoff et al., 1990), or activators of PKC $\lambda$ that use other pathways of lipid metabolism.

\section{A possible physiological role for phosphorylation of olfactory CNG channels}

In an earlier report (Frings, 1993), we have shown that frog OSNs in situ respond more strongly to odorant stimulation when the olfactory epithelium is incubated with phorbol ester, an effect that is probably mediated by PKC. Under conditions of enhanced PKC activity, the stimulus-induced synthesis of cAMP is potentiated so that more $\mathrm{CNG}$ channels can be activated, resulting in an increased receptor current. If such a neurotransmittercontrolled PKC activity is also functional in mammalian OSNs, it affords the neurons with a way of optimizing the transduction efficiency. At increased PKC activity, both cAMP synthesis by the olfactory adenylyl cyclase and the cAMP sensitivity of CNG channels would be high, and weak odorant stimuli are sufficient to elicit electrical excitation. In this speculative concept, phosphorylation of the $\mathrm{CNG}$ channel $\alpha$-subunit contributes to an increase of olfactory sensitivity. Moreover, the $\mathrm{Ca}^{2+}$-dependent adaptation of OSNs may also be affected by channel phosphorylation, because $K_{1 / 2}$ in phosphorylated channels shifts 40 -fold on binding of $\mathrm{Ca}^{2+} /$ calmodulin, instead of sevenfold in control channels. Interestingly, native olfactory $\mathrm{CNG}$ channels respond to calmodulin with a 20-fold (Chen and Yau, 1994) to 60-fold (Balasubramanian et al., 1996) increase of $K_{1 / 2}$. Whether this extended range of modulation reflects a modification of the calmodulin effect by other subunits or is attributable to constitutive phosphorylation of 
the $\alpha$-subunit needs to be clarified in further experiments. Taken together, our results suggest that phosphorylation of the $\alpha$-subunit may influence both excitation and adaptation of OSNs.

In addition to the olfactory epithelium, the olfactory $\mathrm{CNG}$ channel $\alpha$-subunit is also expressed in other tissues, including aorta (Biel et al., 1993) and various parts of the brain (El-Husseini et al., 1995; Kingston et al., 1996; Bradley et al., 1997). Because this channel readily conducts $\mathrm{Ca}^{2+}$, it is expected to function as a $\mathrm{Ca}^{2+}$ entry pathway that couples the cyclic nucleotide metabolism to cytosolic $\mathrm{Ca}^{2+}$ homeostasis in neuronal somata and synaptic terminals. Activation of CNG channels is currently discussed as a factor contributing to synaptic plasticity, neuronal growth, and axon guidance (for review, see Zufall et al., 1997). Considering the substantial increase of ligand sensitivity described here, it is tempting to speculate that phosphorylation of the olfactory CNG channel $\alpha$-subunit in hippocampus, cerebellum, and olfactory bulb contributes to the regulation of neuronal growth and plasticity.

\section{REFERENCES}

Akimoto K, Mizuno K, Osada S, Hirai S, Tanuma S, Suzuki K, Ohno S (1994) A new member of the third class in the protein kinase C family, $\mathrm{PKC} \lambda$, expressed dominantly in an undifferentiated mouse embryonal carcinoma cell line and also in many tissues and cells. J Biol Chem 269:12677-12683.

Altenhofen W, Ludwig J, Eismann E, Kraus W, Bönigk W, Kaupp UB (1991) Control of ligand specificity in cyclic nucleotide-gated channels from rod photoreceptors and olfactory epithelium. Proc Natl Acad Sci USA 88:9868-9872.

Anholt RRH, Mumby SM, Stoffers DA, Girard PR, Kuo JF, Snyder SH (1987) Transduction proteins of olfactory receptor cells: identification of guanine nucleotide binding proteins and protein kinase C. Biochemistry $26: 788-795$

Bakalyar HA, Reed RR (1990) Identification of a specialized adenylate cyclase that may mediate odorant detection. Science 250:1403-1406.

Balasubramanian S, Lynch JW, Barry PH (1995) The permeation of organic cations through cAMP-gated channels in mammalian olfactory receptor neurons. J Membr Biol 146:177-191.

Balasubramanian S, Lynch JW, Barry PH (1996) Calcium-dependent modulation of the agonist affinity of the mammalian olfactory cyclic nucleotide-gated channel by calmodulin and a novel endogenous factor. J Membr Biol 152:13-23.

Bastianelli E, Polans AS, Hidaka H, Pochet R (1995) Differential distribution of six calcium-binding proteins in the rat olfactory epithelium during postnatal development and adulthood. J Comp Neurol 354:395-409.

Baumann A, Frings S, Godde M, Seifert R, Kaupp UB (1994) Primary structure and functional expression of a Drosophila cyclic nucleotidegated channel present in eyes and antenna. EMBO J 13:5040-5050.

Biel M, Altenhofen W, Hullin R, Ludwig J, Freichel M, Flockerzi V, Dascal N, Kaupp UB, Hofmann F (1993) Primary structure and functional expression of a cyclic nucleotide-gated channel from rabbit aorta. FEBS Lett 329:134-138.

Boekhoff I, Breer H (1992) Termination of second messenger signaling in olfaction. Proc Natl Acad Sci USA 89:471-474.

Boekhoff I, Tareilus E, Strotmann J, Breer H (1990) Rapid activation of alternative second messenger pathways in olfactory cilia from rats by different odorants. EMBO J 9:2453-2458.

Boekhoff I, Schleicher S, Strotmann J, Breer H (1992) Odor-induced phosphorylation of olfactory cilia proteins. Proc Natl Acad Sci USA 89:11983-11987.

Boekhoff I, Braunewell KH, Andreini H, Breer H, Gundelfinger E (1997) The calcium-binding protein VILIP in olfactory neurons: regulation of second messenger signaling. Eur J Cell Biol 72:151-158.

Bradley J, Li J, Davidson N, Lester HA, Zinn K (1994) Heteromeric olfactory cyclic nucleotide-gated channels: a new subunit that confers increased sensitivity to cAMP. Proc Natl Acad Sci USA 91:8890-8894.

Bradley J, Zhang Y, Bakin R, Lester HA, Ronnett GV, Zinn K (1997) Functional expression of the heteromeric "olfactory" cyclic nucleotidegated channel in the hippocampus: a potential effector of synaptic plasticity in brain neurons. J Neurosci 17:1993-2005.
Brunet LJ, Gold GH, Ngai J (1996) General anosmia caused by a targeted disruption of the mouse olfactory cyclic nucleotide-gated cation channel. Neuron 17:681-693.

Buck LB (1992) The olfactory multigene family. Curr Opin Neurobiol 2:467-473.

Buck LB, Axel R (1991) A novel multigene family may encode odorant receptors: a molecular basis for odor recognition. Cell 65:175-187.

Chen C, Okayama H (1987) High-efficiency transformation of mammalian cells by plasmid DNA. Mol Cell Biol 7:2745-2752.

Chen TY, Yau KY (1994) Direct modulation by $\mathrm{Ca}^{2+}$-calmodulin of cyclic nucleotide-activated channel of rat olfactory receptor neurons. Nature 368:545-548.

Chen TY, Peng YW, Dhallan RS, Ahamed B, Reed RR, Yau KW (1993) A new subunit of the cyclic nucleotide-gated cation channel in retinal rods. Nature 362:764-767.

Dekker LV (1997) Catalytic specificity of protein kinase C isotypes. In: Protein kinase C (Parker PJ, Dekker LV, eds), pp 57-74. New York: Springer.

Dhallan RS, Yau KY, Schrader KA, Reed RR (1990) Primary structure and functional expression of a cyclic nucleotide-gated channel from olfactory neurons. Nature 347:184-187.

El-Husseini AED, Bladen C, Vincent SR (1995) Expression of the olfactory cyclic nucleotide gated channel (CNG1) in the rat brain. NeuroReport 6:1459-1463.

Firestein S, Zufall F, Shepherd GM (1991) Single odor-sensitive channels in olfactory neurons are also gated by cyclic nucleotides. J Neurosci 11:3565-3572.

Frings S (1993) Protein Kinase C sensitizes olfactory adenylate cyclase. J Gen Physiol 101:183-205.

Frings S, Lynch J, Lindemann B (1992) Properties of cyclic nucleotidegated channels mediating olfactory transduction: activation by cyclic nucleotides, ion selectivity and channel blockage. J Gen Physiol 100:45-67.

Frings S, Seifert R, Godde M, Kaupp UB (1995) Profoundly different calcium permeation and blockage determine the specific function of distinct cyclic nucleotide-gated channels. Neuron 15:169-179.

Gordon SE, Brautigan DL, Zimmerman AL (1992) Protein phosphatases modulate the apparent agonist affinity of the light-regulated ion channel in retinal rods. Neuron 9:739-748.

Goulding EH, Ngai J, Kramer RH, Colicos S, Axel R, Siegelbaum SA, Chess A (1992) Molecular cloning and single-channel properties of the cyclic nucleotide-gated channel from catfish olfactory neurons. Neuron 8:45-48.

Goulding EH, Tibbs GR, Siegelbaum SA (1994) Molecular mechanism of cyclic-nucleotide-gated channel activation. Nature 372:369-374.

Hamill OP, Marty A, Neher E, Sakmann B, Sigworth FJ (1981) Improved patch-clamp techniques for high-resolution current recording from cells and cell-free membrane patches. Pflügers Arch 391:85-100.

Henn DK, Baumann A, Kaupp UB (1995) Probing the transmembrane topology of cyclic nucleotide-gated ion channels with a gene fusion approach. Proc Natl Acad Sci USA 92:7425-7429.

Herlitze S, Koenen M (1990) A general and rapid mutagenesis method using polymerase chain reaction. Gene 91:143-147.

Kingston PA, Zufall F, Barnstable CJ (1996) Rat hippocampal neurons express genes for both rod retinal and olfactory cyclic nucleotide-gated channels: novel targets for cAMP/cGMP function. Proc Natl Acad Sci USA 93:10440-10445.

Körschen HG, Illing M, Seifert R, Sesti F, Williams A, Gotzes S, Colville C, Müller F, Dosé A, Godde M, Molday L, Kaupp UB (1995) A 240 $\mathrm{kDa}$ protein represents the complete $\beta$-subunit of the cyclic nucleotidegated channel from rod photoreceptors. Neuron 15:627-636.

Kozak M (1984) Compilation and analysis of sequences upstream from the translational start site in eukaryotic mRNAs. Nucleic Acids Res 12:857-872.

Kurahashi T (1989) Activation by odorants of cation-selective conductance in the olfactory receptor cell isolated from the newt. J Physiol (Lond) 419:177-192.

Kurahashi T, Kaneko A (1991) High density cAMP-gated channels at the ciliary membrane in the olfactory receptor cell. NeuroReport 2:5-8.

Kurahashi T, Menini A (1997) Mechanism of odorant adaptation in the olfactory receptor cell. Nature 385:725-729.

Leinders-Zufall T, Rand MN, Shepherd GM, Greer CA, Zufall F (1997) Calcium entry through cyclic nucleotide-gated channels in individual cilia of olfactory receptor cells: Spatiotemporal dynamics. J Neurosci 17:4136-4148. 
Levitan IB (1994) Modulation of ion channels by protein phosphorylation and dephosphorylation. Annu Rev Physiol 56:193-212.

Liman ER, Buck LB (1994) A second subunit of the olfactory cyclic nucleotide-gated channel confers high sensitivity to cAMP. Neuron 13:611-621.

Liu DT, Tibbs GR, Siegelbaum SA (1996) Subunit stoichiometry of cyclic nucleotide-gated channels and effects of subunit order on channel function. Neuron 16:983-990.

Liu M, Chen TY, Ahamed B, Li J, Yau KY (1994) Calcium-calmodulin modulation of the olfactory cyclic nucleotide-gated cation channel. Science 266:1348-1354.

Lowe G, Gold GH (1993a) Contribution of the ciliary cyclic nucleotidegated conductance to olfactory transduction in the salamander. J Physiol (Lond) 462:175-196.

Lowe G, Gold GH (1993b) Non-linear amplification by calciumdependent chloride channels in olfactory receptor cells. Nature 366:283-286.

Lowe G, Nakamura T, Gold GH (1989) Adenylate cyclase mediates olfactory transduction for a wide variety of odorants. Proc Natl Acad Sci USA 6:5641-5645.

Ludwig J, Margalit T, Eismann E, Lancet D, Kaupp UB (1990) Primary structure of cAMP-gated channel from bovine olfactory epithelium. FEBS Lett 270:24-29.

Nakamura T, Gold GH (1987) A cyclic nucleotide-gated conductance in olfactory receptor neurons. Nature 325:442-444.

Nishizuka Y (1986) Studies and perspectives of protein kinase C. Science 233:306-312.

Pace U, Hanski E, Salomon Y, Lancet D (1985) Odorant-sensitive adenylate cyclase may mediate olfactory reception. Nature 316:255-258.

Pearson RB, Kemp BE (1991) Protein kinase phosphorylation site se- quences and consensus specificity motifs: tabulations. Methods Enzymol 200:62-81.

Pfeuffer E, Mollner S, Lancet D, Pfeuffer T (1989) Olfactory adenylate cyclase. Identification and purification of a novel enzyme form. J Biol Chem 264:18803-18807.

Sklar PB, Anholt RRH, Snyder SH (1986) The odorant-sensitive adenylate cyclase of olfactory receptor cells. J Biol Chem 261:15538-15543.

Smith RD, Goldin AL (1996) Phosphorylation of brain sodium channels in the I-II linker modulates channel function in Xenopus oocytes. J Neurosci 16:1965-1974.

Swope SL, Moss SJ, Blackstone CD, Huganir RL (1992) Phosphorylation of ligand-gated ion channels: a possible mode of synaptic plasticity. FASEB J 6:2514-2523.

Tareilus E, Noé J, Breer H (1995) Calcium signals in olfactory neurons. Biochim Biophys Acta 1269:129-138.

Tibbs GR, Goulding EH, Siegelbaum SA (1997) Allosteric activation and tuning of ligand efficacy in cyclic-nucleotide-gated channels. Nature 386:612-615.

Van Duuren BL, Tseng SS, Segal A, Smith AC, Melchionne S, Seidman I (1979) Effects of structural changes on the tumor-promoting activity of phorbol myristate acetate on mouse skin. Cancer Res 39:2644-2646.

Varnum MD, Zagotta WN (1997) Interdomain interactions underlying activation of cyclic nucleotide-gated channels. Science 278:110-113.

Zufall F, Firestein S, Shepherd GM (1994) Cyclic nucleotide-gated ion channels and sensory transduction in olfactory receptor neurons. Annu Rev Biophys Biomol Struct 23:577-607.

Zufall F, Shepherd GM, Barnstable CJ (1997) Cyclic nucleotide-gated channels as regulators of CNS development and plasticity. Curr Opin Neurobiol 7:404-412. 